\title{
Water use efficiency of marandu palisadegrass as affected by nitrogen and sulphur rates $^{1}$
}

\author{
Eficiência do uso da água pelo capim-marandu em função de doses de nitrogênio e \\ enxofre
}

\author{
Adriana Guirado Artur ${ }^{2 *}$, Tiago Barreto Garcez ${ }^{3}$ e Francisco Antonio Monteiro ${ }^{3}$
}

\begin{abstract}
This study aimed to evaluate the effects of combination of nitrogen and sulphur fertilizations on water consumption and water use efficiency by marandu palisadegrass (Brachiaria brizantha $\mathrm{cv}$. Marandu). The experiment was carried out in a greenhouse, using a Typic Quartzipsamment. Five nitrogen rates $\left(0 ; 100 ; 200 ; 300\right.$ and $\left.400 \mathrm{mg} \mathrm{dm}^{-3}\right)$ were combined with five sulphur rates $\left(0 ; 10 ; 20 ; 30\right.$ and $\left.40 \mathrm{mg} \mathrm{dm}^{-3}\right)$ in a fractionated $5^{2}$ factorial, with four replications. The leaf area was harvested three times at intervals of approximately 30 days. Soil moisture was maintained at $70 \%$ of capacity retention through a self-irrigating system. There was an increase in consumption and water use efficiency by the forage grass due to the supply of nitrogen and sulphur. Nitrogen fertilization increased the consumption and efficiency of water use in the first growth period (35 days after the transplanting of seedlings). Nitrogen and sulphur supply were more effective in increasing water consumption in the third growth period. For water use efficiency this fact was observed in the second and third growth periods of the Marandu palisadegrass.
\end{abstract}

Key words: Marandu palisadegrass. Plants and water. Plants-nitrogen effect. Plants-sulphur effects.

RESUMO - Neste estudo objetivou-se avaliar a combinação de doses de nitrogênio e enxofre no consumo e eficiência do uso da água pela Brachiaria brizantha cv. Marandu. O experimento foi conduzido em casa de vegetação, utilizando-se um solo classificado como Neossolo Quartzarênico Órtico típico. Cinco doses de nitrogênio $\left(0 ; 100 ; 200 ; 300\right.$ e $\left.400 \mathrm{mg} \mathrm{dm}^{-3}\right)$ foram combinadas com cinco doses de enxofre $\left(0 ; 10 ; 20 ; 30\right.$ e $\left.40 \mathrm{mg} \mathrm{dm}^{-3}\right)$ em um fatorial $5^{2}$ fracionado, com quatro repetições. A parte aérea do capim foi cortada três vezes em intervalos aproximados de 30 dias. A água do solo foi mantida a $70 \%$ da capacidade de retenção por meio de um sistema autoirrigante. Ocorreu aumento no consumo e na eficiência do uso da água pela gramínea forrageira em razão do fornecimento de nitrogênio e enxofre. A adubação com nitrogênio incrementou o consumo e a eficiência no uso da água no primeiro período de crescimento (35 dias após o transplantio das mudas). O fornecimento simultâneo de doses de nitrogênio e enxofre foi mais efetivo no aumento do consumo de água no terceiro período de crescimento. Para a eficiência no uso da água esse efeito foi observado no segundo e terceiro períodos de crescimento do capim-marandu.

Palavras-chave: Capim-marandu. Plantas e água. Plantas-efeito do nitrogênio. Plantas-efeito do enxofre.

\footnotetext{
*Autor para correspondência

Recebido para publicação em 10/09/2012; aprovado em 09/10/2013

Parte da Tese de Doutorado do primeiro autor apresentada na Universidade de São Paulo/ESALQ/USP, projeto apoiado pela Fundação de Amparo à Pesquisa do Estado de São Paulo/FAPESP e Conselho Nacional de Desenvolvimento Científico e Tecnológico/CNPq

${ }^{2}$ Departamento de Ciência do Solo, Universidade Federal do Ceará, Av. Mister Hull, 2977, Campus do Pici, Fortaleza-CE, Brazil, 60.021-970, driguirado@yahoo.com.br

32Departamento de Ciência do Solo, Universidade de São Paulo, Caixa Postal 9, Piracicaba-SP, Brazil, 13.418-900, tiagobgarcez@hotmail.com, famontei@usp.br
} 


\section{INTRODUCTION}

Water is a renewable resource, but its availability is variable and limited in many planet regions. It is, therefore, important to develop techniques to improve water use efficiency in agricultural systems in order to minimize the competition between agriculture and urban society for limited water resources.

It is estimated that pastures in Brazil account for $25 \%$ of the land area, which highlights the importance of forage plants in the national scenario, mainly because they constitute main food source to ruminants. Around $85 \%$ of the total grassland area in the country is currently cultivated with the genus Brachiaria, due to its productivity and adaptation to climatic conditions of tropical and subtropical regions (LAZZARINI NETO, 2000).

Water, besides being the main constituent of protoplasm, is directly involved in many chemical reactions. Therefore, reduction in water uptake by plants contributes to cell dehydration and adaptive changes in plant growth and physio-biochemical processes, such as changes in plant structure, growth rate, tissue osmotic potential and antioxidant defenses (DUAN et al., 2007). According to Volenec and Nelson (2003), low water availability in soil causes the plant stomata to close, reducing $\mathrm{CO}_{2}$ assimilation, transpiration, leaf expansion and allocation of photo assimilates to organs. The low water availability can cause the deficiency of some nutrients due to the difficulty of the plant to absorb them in these conditions. This depends upon intensity and duration of water stress, as well as plant species and its stage of development (CHAVES; MAROCO; PEREIRA, 2003).

Water consumption by plant is influenced by the availability of soil water, atmospheric evaporative demand, morpho-physiological species characteristics, stages in the cycle of growth and leaf area. Water flow from soil to plant and from there to the atmosphere depends on the soil watercontent and on the transport through plant organs to the leaves, where the regulation of the transpiration flow occurs.

Water use efficiency is defined as crop yield per unit of water consumed or, in biological terms, as the carbohydrate formed in photosynthesis by $\mathrm{CO}_{2}$ assimilation, solar light and amount of water transpired (SINCLAIR; TANNER; BENNETT, 1984). Water consumption and water use efficiency by crops depend on soil physical conditions, atmospheric conditions and plant characteristics.

With regard plant nutritional aspect, nitrogen is the main nutrient for crop productivity (BARBANTI; MONTI; VENTURI, 2007) especially for forage species. Because of the interdependence of biochemical pathways of nitrogen and sulphur in protein synthesis, sulphur can interfere with the response of forage grasses to nitrogen fertilization and these nutrients combination can affect their yield (BONFIM-SILVA; MONTEIRO; SILVA, 2007; DE BONA; MONTEIRO, 2008).

Absorption of nutrients depends, among other factors, on the availability of water (LAL et al., 2006), and for both nitrogen and sulphur contents in soil. Under water deficit conditions, the amount of nutrients absorbed by plants is reduced, which directly affects the morphogenesis of forage grasses and, indirectly, the pasture structural canopy. Water and nutrients by the crop varies with the stage of plant development and that the initial growth has a direct influence on other stages of the life plants cycle.

This research aimed to evaluate the effects of applying a combination of nitrogen and sulphur rates on water consumption and water use efficiency by Brachiaria brizantha cv. Marandu (marandu palisadegrass). The experiment will be carried out during three growth periods in a Typic Quartzipsamment with very low organic matter and sulfate-sulphur contents.

\section{MATERIAL AND METHODS}

This study was conducted under greenhouse conditions in Piracicaba, São Paulo State Brazil (22 $43^{\prime} \mathrm{S}, 4^{\circ} 38^{\prime} \mathrm{W}$ ) from September to December 2008. The average air temperature in the greenhouse during the experimental period was approximately $33{ }^{\circ} \mathrm{C}$. Marandu palisadegrass (Brachiaria brizantha cv. Marandu) grow in plastic pots with a capacity of 4.2 $\mathrm{L}$, filled with soil that exhibited low organic matter content $(0.95 \%)$ and had a $\mathrm{pH} \mathrm{CaCl}_{2}=4.0$.

\section{Soil sample}

Composite samples of a Typic Quartzipsamment were collected at $0-20 \mathrm{~cm}$ of depth, air-dried, sieved to pass through a $4 \mathrm{~mm}$ screen to remove pebbles and large organic fractions such as roots and leaves and mixed. Chemical characteristics showed the following results (SILVA et al., 2006): $\mathrm{P}$ resin $=3 \mathrm{mg} \mathrm{dm}^{-3} ; \mathrm{OM}=9.5 \mathrm{~g}$ $\mathrm{dm}^{-3} ; \mathrm{pH}$ in $\mathrm{CaCl}_{2}=4.0 ; \mathrm{K}^{+}=2.3 \mathrm{mmol}_{\mathrm{c}} \mathrm{dm}^{-3} ; \mathrm{Ca}^{2+}=6$ mmol $\mathrm{dm}^{-3} ; \mathrm{Mg}^{2+}=2 \mathrm{mmol} \mathrm{dm}^{-3} ; \mathrm{Al}^{3+}=8 \mathrm{mmol} \mathrm{dm}^{-3}$; $\mathrm{H}+\mathrm{Al}^{\mathrm{c}}=40 \mathrm{mmol}_{\mathrm{c}} \mathrm{dm}^{-3} ; \mathrm{CEC}^{\mathrm{c}}$ at $\mathrm{pH} 7.0=50.3 \mathrm{mmol}_{\mathrm{c}}$ $\mathrm{dm}^{-3}$; sum of bases ( $\left.\mathrm{SB}\right)=10.3 \mathrm{mmol} \mathrm{dm}^{-3}$; base saturation $(\mathrm{V})=20 \% ; \mathrm{S}_{-} \mathrm{SO}_{4}{ }^{2-}=2.6 \mathrm{mg} \mathrm{dm}^{-3} ;$ total- $\mathrm{N}=400 \mathrm{mg} \mathrm{dm}^{-3}$. Soil texture showed: $75.1,126.3$ and $798.6 \mathrm{~g} \mathrm{dm}^{-3}$ of clay, silt and sand. Liming to achieve $50 \%$ was done by using calcium carbonate and magnesium carbonate (WERNER et al., 1996). Soil moisture was maintained at $70 \%$ of soil retention capacity with deionized water for incubation during 35 days. 
Combinations of five nitrogen rates $(0 ; 100 ; 200 ; 300$ and $\left.400 \mathrm{mg} \mathrm{dm}^{-3}\right)$ with five of sulphur $(0 ; 10 ; 20 ; 30$ and $40 \mathrm{mg} \mathrm{dm}^{-3}$ ) were studied in fractionated $5^{2}$ factorial, according to Littell and Mott (1975). Thirteen combinations between nitrogen and sulphur rates were: $0-0 ; 0-20 ; 0-40$; $100-10 ; 100-30 ; 200-0 ; 200-20 ; 200-40 ; 300-10 ; 300-30$; 400-0; 400-20 and 400-40 $\mathrm{mg} \mathrm{dm}^{-3}$, distributed in randomized blocks design, with four replications. Nitrogen and sulphur were applied though ammonium nitrate and sulfate calcium, respectively, and the amount of calcium were balanced by using calcium chloride in solution form. Every grass growth, sulfur rates were applied once and nitrogen rates were split into four applications, with interval of two days between them.

The fertilizations with macronutrients to the establishment of grass were: phosphorus $=200 \mathrm{mg} \mathrm{dm}^{-3}$; potassium $=150 \mathrm{mg} \mathrm{dm}^{-3}$ and magnesium $=50 \mathrm{mg} \mathrm{dm}^{-3}$, which were supplied after nitrogen application with interval of two days between application by the following sources: $\mathrm{Ca}\left(\mathrm{H}_{2} \mathrm{PO}_{4}\right)_{2}, \mathrm{KH}_{2} \mathrm{PO}_{4}, \mathrm{KCl}$ and $\mathrm{MgCl}_{2} \cdot 6 \mathrm{H}_{2} \mathrm{O}$. Fertilizations were repeated for every grass regrowth to supply nitrogen and sulphur at the same rates and amounts applied for the initial growth, respectively. The additional supply of magnesium was $20 \mathrm{mg} \mathrm{dm}^{-3}$ due to non-application of phosphorus after the first harvest. Boron, copper, zinc and molybdenum were supplied before grass planting with the following sources and amounts: $\mathrm{H}_{3} \mathrm{BO}_{3}=1.5 \mathrm{mg} \mathrm{dm}^{-3}, \mathrm{CuCl}_{2} .2 \mathrm{H}_{2} \mathrm{O}=2.5 \mathrm{mg} \mathrm{dm}^{-3}$, $\mathrm{ZnCl}_{2}=2.0 \mathrm{mg} \mathrm{dm}^{-3}$ and $\mathrm{Na}_{2} \mathrm{MoO}_{4} \cdot 2 \mathrm{H}_{2} \mathrm{O}=0.25 \mathrm{mg} \mathrm{dm}^{-3}$.

\section{Irrigation system}

Soil moisture was maintained by a subsurface selfirrigated system prepared as described in Bonfim-Silva, Monteiro and Silva (2007), which allowed the continuous water replacement according to evapotranspiration, of the soil-plant system, ensuring the soil water retention capacity. This irrigation system was composed of pottery capsule $(5 \mathrm{~cm}$ diameter and $7 \mathrm{~cm}$ height), inserted into the soil and a water reservoir (Mariotte tube) connected by flexible silicone microtubes to keep the reservoir capacity of $1.8 \mathrm{~L}$ with constant water level. The replacements of water in this reservoir were made when necessary. Water potential in the soil was established by the height of the water column between the pot and tank (height $=30$ $\mathrm{cm}$ ), corresponding to the controlled tension of $3 \mathrm{kPa}$ and water content in the soil of approximately $70 \%$ of the field capacity. Thus, the grass transpiration secured automatic replenishment of water to the soil, making system selfirrigated. A scale of level externally attached to the reservoir allowed the quantification of water use in each experimental unit. The irrigation methodology minimizes the formation of anaerobic micro sites within the soil body in the pot.

\section{Plant development}

In the experiment with plants, five seedlings of marandu palisadegrass were cultivated per pot. Plants were harvests three times in the following growth periods: 35 days after the transplanting of seedlings (first growth period), 28 days after the first harvest (second growth period) and 27 days after the second harvest (third growth period). The plants were harvest $5 \mathrm{~cm}$ above the soil surface and all material collected were dried in a forced air ventilated oven at $65{ }^{\circ} \mathrm{C}$ until constant mass was achieved and subsequently weighed.

Partial values of water consumption were determined every two days and total accumulated was calculated each growth forage grass period.

The water use efficiency, expressed through the ratio dry mass/water consumed by marandu palisadegrass, was calculated based on combinations of nitrogen and sulphur fertilizations.

\section{Statistical analysis}

Water consumption and water use efficiency were analyzed using the Statistical Analysis System (SAS INSTITUTE, 2008). When the significance interaction of nitrogen rates $\mathrm{x}$ sulphur rates was observed, the PROC RSREG was used. When that interaction was not significant regression analysis for the components of the first and second degree was performed using the PROC GLM. Significance level of $5 \%$ was used for all statistical tests.

\section{RESULTS AND DISCUSSION}

Water consumption by marandu palisadegrass varied with the growth period of the grass (Figure 1). Results of water consumption in the first and second periods of grass growth showed significant effects only for nitrogen rates. However, in the third period of growth, significance was found for the interaction of nitrogen rates $x$ sulphur rates in terms of the amount of water consumed by plants.

The maximum water consumption $(7936 \mathrm{~mL} / \mathrm{pot})$ during the first grass growth period was observed at the $297 \mathrm{mg} \mathrm{dm}^{-3}$ nitrogen rate (Figure 1a), corresponding to an average daily consumption of $226.7 \mathrm{~mL} /$ pot. Part of the water counted as consumed by plants during this period was lost through evaporation from the soil surface and not properly used in plant metabolism. In the second growth period, maximum water consumption (13503 mL/pot) was observed at the $321 \mathrm{mg} \mathrm{dm}^{-3}$ nitrogen rate (Figure $1 \mathrm{~b}$ ) and the average daily consumption was $482.3 \mathrm{~mL} /$ pot. It was observed that at the $321 \mathrm{mg} \mathrm{dm}^{-3}$ nitrogen rate in the first growth period, water consumption was 2.1 times lower than water consumption in the second grass growth period.

By increasing the nitrogen supply in the first growth period, during 35 days after the transplanting of seedlings (early stage of establishment of the grass), water 
consumption was not increased, and this can be explained by the small grass leaf area. Thus, the plants had little uptake, translocation and transpiration of water, there was water evaporation from the soil surface, besides the small root density with soil depth, which resulted in lower extraction of water and soil nutrients because the root system was in formation. According to Bergamaschi et al. (2004), in the early period of the plants development, the effect of leaf area is reduced, and evaporation from the soil tends to be higher, but it loses importance when the leaf area is sufficient to reduce the exposed area of the soil.

From the second growth period of grasses onwards, root system was already formed, plant metabolism became more intense, the increased leaf area caused greater interception of incident solar energy and therefore higher assimilation of carbon. As a result, the grass increased water consumption.

The amount of water absorbed by roots depends on the amount of available soil water for the plant, aeration, soil temperature, solution concentration and transpiration rate of the plant. It was observed that for both the first and the second growth periods of the marandu palisadegrass, there was no significant response to the applied sulphur rates. For the forage grass establishment, the native sulphur content in the soil might have been sufficient to satisfy the forage plant requirements. This availability of sulphur in the soil can be attributed to fertilization with sulphur and mineralization of soil organic matter (NZIGHEBA; SMOLDERS; MERCKX, 2005), stimulated by high temperature and adequate soil moisture in the pots.

At the time of conducting the third period of plant growth, the temperature in the greenhouse reached the highest levels (maximum of $43{ }^{\circ} \mathrm{C}$ ), which increased transpiration and decreased stomatal conductance. High values of water consumption and dry matter production were observed in this period in comparison to the first growth period of the grass.

Nitrogen and sulphur rates, which promoted the maximum water consumption, were 329 and $31 \mathrm{mg} \mathrm{dm}^{-3}$, respectively (Figure 1c), with $\mathrm{N}: \mathrm{S}$ fertilization ratio of 10.6:1 and average daily water consumption by the forage grass of $492.8 \mathrm{~mL} /$ pot.

The increase in water consumption by marandu palisadegrass with the combination of nitrogen rates and sulphur rates (Figure 1c) is directly related to positive effect on the increase of dry matter production of the grass provided by the concomitant supply of these nutrients.

Nitrogen and sulphur have roles in plants that are responsible for increasing production and even though the amount of sulphur required by plants is small, sulphur is closely related to nitrogen metabolism (CRAWFORD et al., 2000). Thus, it was observed that fertilization with nitrogen and sulphur had indirect effect on water consumption through the physiology of forage grasses. However, it is known that if the soil does not have adequate soil water availability, nutrient absorption may be limited. In this experiment, water was provided by a self-irrigating system, which maintained the soil moisture at $70 \%$ of water retention capacity throughout the experiment, not being, therefore, a limiting factor for nutrients absorption. Bittman and Simpson (1987) observed that under low water availability in the soil, the grass leaf area is reduced because the balance between the productions of assimilates and the demand for the development of the reproductive organs is affected.

Analyzing water consumption in the three growth periods of the grass, it was observed that, in relation to the total cycle, water consumption during the initial phase of development was around $26.2 \%$, considering only the first 35 days. This water consumption was low compared to the $38.9 \%$ in the second growth period, stage in which the culture reached its maximum growth and development, demanding greater quantities of water. For the third growth period, water consumption accounted for $34.9 \%$ of total water consumed by the marandu palisadegrass throughout the developmental cycle.

De Bona and Monteiro (2008), for the same grass and soil with very high content of organic matter and sulfate-sulphur observed significance for the interaction of nitrogen $x$ sulphur rates in the second and third growth periods. Bonfim-Silva, Monteiro and Silva (2007) for Brachiaria decumbens in the first growth period observed that this forage grass needs a higher requirement for sulphur in relation to marandu palisadegrass. According to Havlin et al. (2005) the low sulphur content available from organic matter mineralization was not sufficient to meet the culture need for this nutrient in the developmental period.

In the first and second growth periods there was significant response only to the nitrogen rates. Despite the differences in contents of organic matter and sulfate - sulphur in the studied soils, the requirement for sulphur by marandu palisadegrass in the establishment phase was low, being also related to lower dry matter production in this period and therefore lower water consumption by the plant. For the Signal grass (Brachiaria decumbens), the increased forage yield demanded high nitrogen rates combined with high sulphur rates and, therefore, higher water consumption by the plant.

Nutrients demand varies with plant species, plant developmental stage and their uptake will depend on the availability of nutrients and soil water. According to Petry et al. (2007), crop sets the extraction speed of soil water, which also varies with time, due to the increase in leaf area and the expansion of the root system. 
Figure 1 - Water consumption in the first and second growth periods of marandu palissadegrass fertilized with nitrogen rates ( $\mathrm{a}$ and $\mathrm{b}$ ) and in the third growth period (c) as related to combinations of nitrogen $x$ sulphur rates
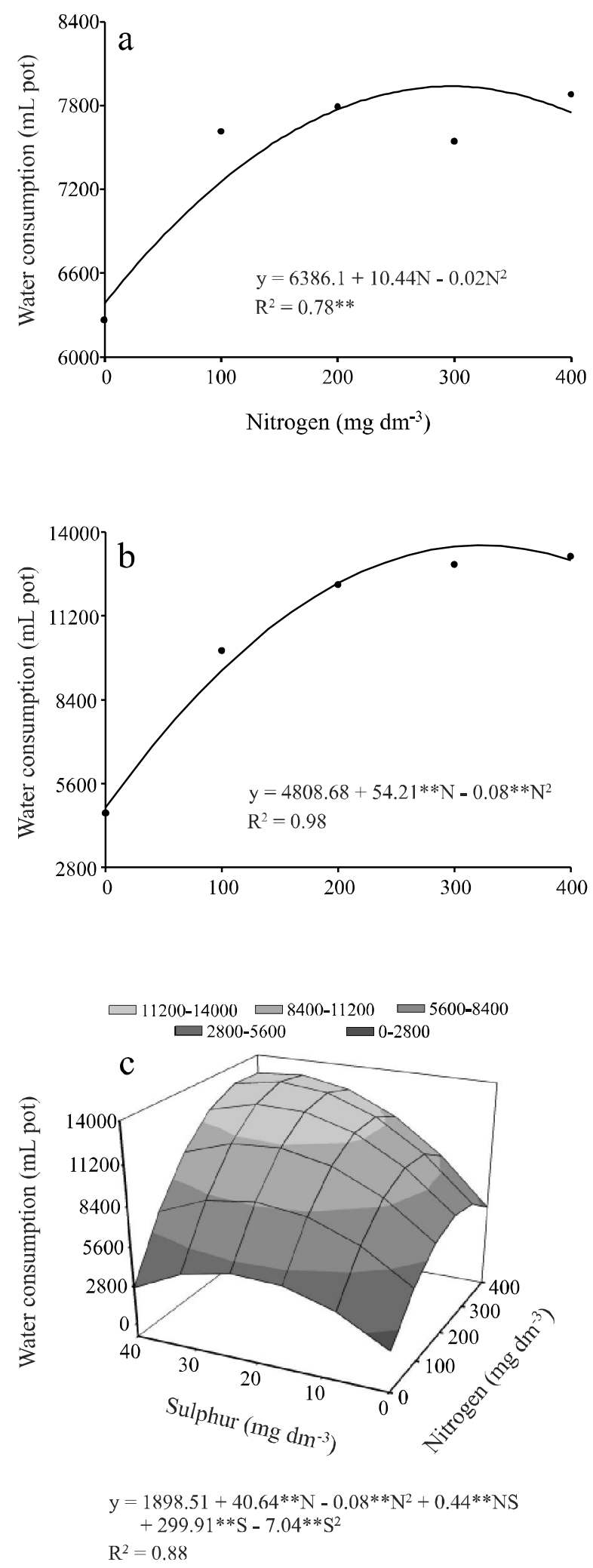

Water use efficiency in the first growth period of grass was significantly influenced by nitrogen fertilization (Figure 2a). The nitrogen rate of $219 \mathrm{mg} \mathrm{dm}^{-3}$ provided the highest water use efficiency $\left(2 \mathrm{~g} \mathrm{~L}^{-1}\right)$ and nitrogen supply up to $250 \mathrm{mg} \mathrm{dm}^{-3}$ resulted in increased efficiency of water use by the forage grass in the first growth period (Figure 2a). Water is important for the formation and transport of all soluble substances, photosynthates and carbohydrates from the source to the transformation into dry matter in the grass part area. In addition, the water absorbed by the plant is an important way of conducting dissolved nutrients from the soil to the root surface, so that absorption occurs (TAIZ; ZEIGER, 2004), being very significant for nitrogen and sulphur, which are absorbed by mass flow.

De Bona and Monteiro (2008) found that nitrogen is essential for the marandu palisadegrass, and nitrogen rates which provided the maximum water use efficiency of the soil for grass dry matter production were 336 and $254 \mathrm{mg} \mathrm{dm}^{-3}$, respectively.

Cabrera-Bosquet et al. (2007) for hard wheat (Triticum durum) observed that the plant used water more efficiently when subjected to high nitrogen rates, providing increased production of dry matter. The greatest leaf area and sufficient nitrogen increased ground cover and had an important influence in water use efficiency, reducing soil evaporation and increasing plant dry mass accumulation (IGBAL et al., 2011). Dordas and Sioulas (2008) observed that nitrogen fertilization can influence the amount of water extracted by a crop and crop growth, and consequently can affect water use efficiency.

Dordas and Sioulas (2008), for Safflower (Carthamus tinctorius L.), showed that the nitrogen is very important for the growth and yield. Nitrogen application increased assimilation rate, stomatal conductance of water vapour by an average and water use efficiency over the 2 years of the study when compared to the control. Moriana, Villalobos and Fereres (2002) reported a relationship between stomatal conductance and water in the olive.

According to Correia et al. (2005), the supply of high nitrogen rates affect the carbon assimilation rate, since this nutrient is one of the main components of the photosynthetic system, such as chlorophyll, carboxylase/oxygenase of ribulose 1.5 bisphosphate (RubisCO) and carboxylase of phosphoenolpyruvate (PEPcase). The relation between nitrogen and photosynthesis increases water use efficiency by the plant. Water use efficiency is related to photosynthesis, stomata are closed (EDWARDS et al., 2010), to lower rates transpiration associated with a higher leaf area 
per unit plant dry mass (IGBAL et al., 2011) and to water potential in the soil.

Silva et al. (2012) found that forage dry matter production increased when the temperature reached higher values. Therefore, it is possible to assume that temperature may have affected plant physiology during the processes of absorption and translocation of nutrients and affect water use efficiency by plants. Water stress on crop plants cause reduction in fresh, dry biomass production (ZHAO et al., 2006), and limits plant growth (TOHIDI-MOGHADAM et al., 2009).

For the production of each $55 \mathrm{~kg} \mathrm{ha}^{-1}$ of dry matter per mm of water transpired, the plant responds to nitrogen uptake by mass flow of $0.65 \mathrm{~kg} \mathrm{ha}^{-1}$. For the second and third growth periods, there was significant interaction nitrogen rate $x$ sulphur rate on water use efficiency by the forage plant, noting that, within any of the sulphur rates, as the nitrogen rate was increased, the grass was more efficient in water use (Figure 2b and 2c). Water use efficiency in both the second and third growth periods of the forage grass reached the maximum level around $3 \mathrm{~g} \mathrm{~L}^{-1}$ (Figure $2 \mathrm{~b}$ and $2 \mathrm{c}$ ). The values of water use efficiency found in this experiment agree with those obtained by De Bona and Monteiro (2008) who studied nitrogen rates and sulphur rates for marandu palisadegrass in a soil with $32,1 \mathrm{~g} \mathrm{dm}^{-3}$ of organic matter and 7,4 $\mathrm{mg} \mathrm{dm}^{-3}$ of sulphur.

Bonfim-Silva, Monteiro and Silva (2007) for Signal grass, applying the same nitrogen and sulphur rates, observed values of water use efficiency of $3 \mathrm{~g} \mathrm{~L}^{-1}$ for the first growth period of the grass and values close to $7 \mathrm{~g} \mathrm{~L}^{-1}$ for the second and third growth periods of the plant. It is worth mentioning that all these experiments, including the current study, were carried out using an irrigation system, i.e., the availability of water in the soil was constant throughout the experiment, water deficit did not occur and it was not a limiting factor for plant development.

Several authors found similar resulted as that obtained is this study, indicating that the simultaneous supply of nitrogen and sulphur, maximized the use of available water by forage grass. Thus, the organic matter content and sulfate-sulphur in the soil were not indicative of the needs of fertilization with nitrogen and sulphur to the establishment of marandu palissadegrass.

The lack of response to sulphur was due to low demand of marandu palisadegrass in the establishment phase. Simultaneous nitrogen and sulphur supply maximizes the benefits of forage grass to nitrogen fertilization, so sulphur should be considered in the pasture after the initial establishment phase.
Figure 2 - Water use efficiency in the first growth period of marandu palissadegrass fertilized with nitrogen rates (a) and in the second and third growth periods (b and c) as related to combinations of nitrogen $x$ sulphur rates
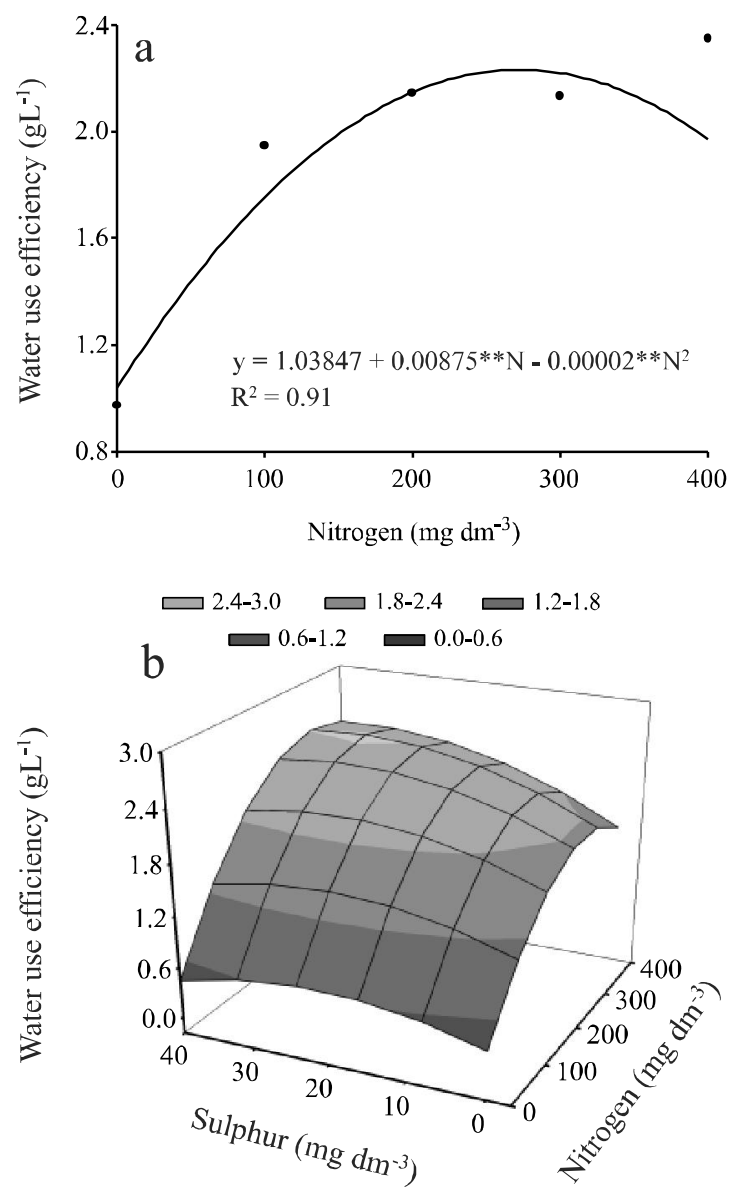

$$
\begin{aligned}
\mathrm{y}= & 0.37152+0.01014 * * \mathrm{~N}-0.00002 * * \mathrm{~N}^{2} \\
& +0.00005^{* *} \mathrm{NS}+0.02770 * * \mathrm{~S}-0.00066^{* *} \mathrm{~S}^{2} \\
\mathrm{R}^{2}= & 0.92
\end{aligned}
$$

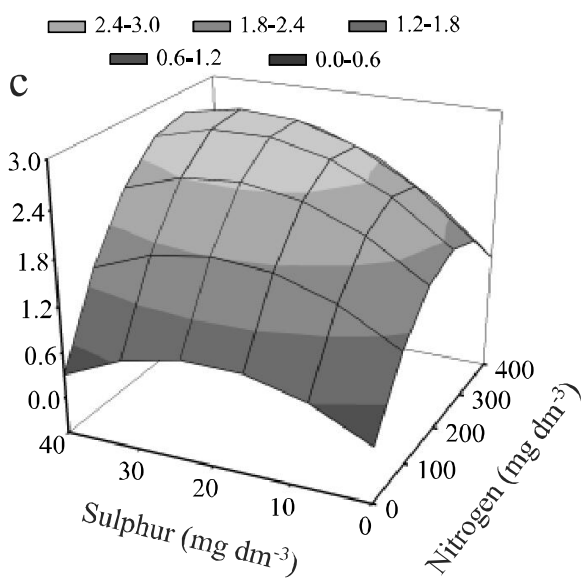

$$
\begin{aligned}
\mathrm{y}= & 0.23695+0.01243^{* *} \mathrm{~N}-0.00003^{* *} \mathrm{~N}^{2} \\
& +0.00008^{* *} \mathrm{NS}+0.05841^{* *} \mathrm{~S}-0.00142^{* *} \mathrm{~S}^{2}
\end{aligned}
$$$$
\mathrm{R}^{2}=0.84
$$ 


\section{CONCLUSION}

Despite the low organic matter content $\left(9.5 \mathrm{~g} \mathrm{dm}^{-3}\right)$ and sulfate-sulphur $\left(2.6 \mathrm{mg} \mathrm{dm}^{-3}\right)$, the grass in the establishment phase only respond to nitrogen supply. In the development phase of forage grass is necessary to apply nitrogen and sulphur simultaneously. A sharp increase in water consumption and water use efficiency by Brachiaria brizantha cv. Marandu is due to the simultaneous supply of nitrogen and sulphur. Well nourished plants with nitrogen and sulphur become more efficient in the use of available water.

\section{REFERENCES}

BARBANTI, L.; MONTI, A.; VENTURI, G. Nitrogen dynamics and fertilizer use efficiency in leaves of different ages of sugar beet (Beta vulgaris) at variable water regimes. Annals of Applied Biology, v. 150, n. 2, p. 197-205, 2007.

BERGAMASCHI, H. et al. Distribuição hídrica no período crítico do milho e produção de grãos. Pesquisa Agropecuária Brasileira, v. 39, n. 9, p. 831-839, 2004.

BITTMAN, S.; SIMPSON, G. M. Soil water deficit effect on yield, leaf area, and net assimilation rate of three forage grasses: crested wheatgrass, Madison smooth bromegrass and altai wildrye. Agronomy Journal, v. 79, n. 5, p. 768-774, 1987.

BONFIM-SILVA, E. M.; MONTEIRO, F. A.; SILVA, T. J. A. Nitrogênio e enxofre na produção e no uso de água pelo capimBraquiária em degradação. Revista Brasileira de Ciência do Solo, v. 31, p. 309-317, 2007.

CABRERA-BOSQUET, L. et al. The combined effect of constant water deficit and nitrogen supply on WUE, NUE and $\Delta^{13} \mathrm{C}$ in durum wheat potted plants. Annals of Applied Biology, v. 151, n. 3, p. 277-289, 2007.

CHAVES, M. M.; MAROCO, J.P.; PEREIRA, J. S. Understanding plant responses to drought: from genes to the whole plant. Functional Plant Biology, v. 30, n. 3, p. 239-264, 2003.

CORREIA, C. M. et al. Ultraviolet-B radiation and nitrogen affect the photosynthesis of maize: a Mediterranean field study. European Journal of Agronomy, v. 22, n. 3, p. 337-347, 2005.

CRAWFORD, N. M. et al. Nitrogen and sulphur. In: BUCHANAN, B. B.; GRUISSEM, W.; JONES, R. L. (Ed.). Biochemistry and molecular biology of plants. American Society of Plant Physiologists, 2000. chap. 16, p. 786- 849.

DE BONA, F. D.; MONTEIRO, F. A. Nitrogênio e enxofre na eficiência do uso da água pelo capim-Marandu em estabelecimento. Ecossistema, v. 32, p. 17-22, 2008.

DORDAS, C. A.; SIOULAS, C. Safflower yield, chlorophyll content, photosynthesis, and water use efficiency response to nitrogen fertilization under rainfed conditions. Industrial Crops and Products, v. 27, n. 1, p. 75-85, 2008.
DUAN B. et al. Interactions between drought stress, ABA and genotypes in Picea asperata. Journal of Experimental Botany, v. 58, n. 11, p. 3025-3036, 2007.

EDWARDS E. J. et al. The origins of C4 grasslands: integrating evolutionary and ecosystem science. Science, v. 328, n. 5978, p. $587-591,2010$.

HAVLIN, J. L. et al. Soil Fertility and Nutrient Management: An Introduction to Nutrient Management. $7^{\text {th }}$ ed. Nova Jersey: Pearson/Prentice Hall, 2005. 515 p.

IGBAL, N. et al. Exogenously-sourced ethylene increases stomatal conductance, photosynthesis, and growth under optimal and deficient nitrogen fertilization in mustard. Journal of Experimental Botany, v. 62, n.14, p. 4955-4963, 2011.

LAL, C. et al. Gene action for surrogate traits of water-useefficiency and harvest index in peanut (Arachis hypogaea). Annals of Applied Biology, v. 148, n. 2, p. 165-172, 2006.

LAZZARINI NETO, S. Manejo das pastagens. 2. ed. Viçosa: Aprenda Fácil, 2000. 124 p.

LITTELL, R. C.; MOTT, G. O. Computer assisted design and analysis of response surface experiments in agronomy. Soil and Crop Society of Florida Proceedings, v. 34, p. 94-97, 1975.

MORIANA, A.; VILLALOBOS, F. J.; FERERES, E. Stomatal and photosyntetic responses of olive (Olea europaea L.) leaves to water déficits. Plant Cell Environment, v. 25, n. 3, p. 395-405, 2002.

NZIGHEBA, G.; SMOLDERS, E.; MERCKX, R. Sulphur immobilization and availability in soils assessed using isotope dilution. Soil Biology and Biochemistry, v. 37, n. 4, p. 635644, 2005.

PETRY, M. T. et al. Disponibilidade de água do solo ao milho cultivado sob sistemas de semeadura direta e preparo convencional. Revista Brasileira de Ciência do Solo, v. 31 , n. 03, p. 531-539, 2007.

SILVA, F. C. et al. Métodos de análises químicas para avaliação da fertilidade do solo. In: SILVA, F. C. 2. Ed. Manual de análises químicas de solos, plantas e fertilizantes, 2006. p. 627.

SILVA, E. A. et al. Dry matter yield, thermal sum and base temperatures in irrigated tropical forage plants. Revista Brasileira Zootecnia, v. 41, n. 03, 2012.

SAS INSTITUTE. SAS/STAT: Qualification Tools user's guide, version 9.2 Cary, 2008.

SINCLAIR, T. R.; TANNER, C. B.; BENNETT, J. M. Water use efficiency in crop production. BioScience, v. 34, n. 1, p. 36-40, 1984.

TAIZ, L.; ZEIGER, E. Fisiologia vegetal. Porto Alegre: Artmed, 2004. 719 p.

TOHIDI-MOGHADAM, H. R. et al. Response of six oilseed rape genotypes to water stress and hydrogel application. Pesquisa Agropecuária Tropical, v. 39, n. 3, p. 243-250, 2009. 
VOLENEC, J. J.; NELSON, C. J. Integrative environmental and physiological aspects of forage management: the science of grassland agriculture. In: BARNES, R. F.et al. (Ed.). Forages: an introduction to grassland agriculture. Ames: Iowa State University Press, 2003. p. 99-124.

WERNER, J. C. et al. Forrageiras. In: RAIJ, B. Van et al. (Ed.). Recomendações de adubação e calagem para o Estado de São Paulo. Campinas: Instituto Agronômico, 1996. p.263273. (IAC. Boletim Técnico, 100).

ZHAO T. J. et al Regulating the drought-responsive element (DRE)-mediated signaling pathway by synergic functions of trans-active and transinactive DRE binding factors in Brassica napus. Journal of Biological Chemistry, v. 281, n. 16, p. 10752-10759, 2006. 